\title{
The Continued Criminality of Selling Sex: A Trajectory of South African Sex Work Law Reform
}

\author{
Amanda Spies* (1) \\ Nelson Mandela University, Port Elizabeth, South Africa \\ amanda.spies@mandela.ac.za
}

\begin{abstract}
This article explores the regulation of sex work in South Africa and follows the trajectory of the South African Law Reform Commission (SALRC) in investigating whether sex work should be decriminalized. The legal regulation of sex work is a hotly contested topic. South Africa currently criminalizes the selling and buying of sex, but policy reform has been on the cards since the SALRC launched its project on the topic in the early 2000s. As most sex work policy responses are grounded in feminist theory, the article analyses the main theoretical ideologies and questions the influence of these ideologies in structuring sex work law reform in the South African context. The author calls for a more inclusive understanding of feminism and sex work, and the need to acknowledge the importance of rights discourse in furthering political growth and protecting sex workers' constitutional rights.
\end{abstract}

\section{Keywords}

Sex work, decriminalization, feminism, constitutional rights

\section{INTRODUCTION}

The decriminalization of sex work has been a contested and controversial topic on the South African legal reform agenda, as it has been on many agendas worldwide. ${ }^{1}$ The South African Law Reform Commission's (SALRC) 2017

Associate professor, Faculty of Law, Nelson Mandela University, South Africa.

1 The researcher acknowledges that sex work not only involves women but also incorporates a broad spectrum of activity and individuals, including men, women, children and individuals from the transgender community. However, as most sex workers are women and this research explores feminist arguments in relation to sex work, "sex workers" in this context refers to women. The choice of terminology in referring to sex work/prostitution and sex worker/prostitute is also contested between feminists, and often indicative of which specific theoretical understanding of feminism one supports. Liberal feminists prefer the term sex work/sex workers, stressing women's agency, whilst radical feminists prefer the term prostitute/prostitution as it is indicative of women's 
report that concluded an 18-year project was received with disappointment as it recommended the continued criminalization of sex work despite governments seeming commitment to decriminalization. ${ }^{2}$ Considering the conflicting outcome, it has therefore become important to understand the regulation of sex work in South Africa (and elsewhere) and how best to respond to sex workers' rights claims.

In South African law, selling sex is a crime and the Sexual Offences Act 23 of 1957 states that any person who has unlawful carnal intercourse, or commits any act of indecency for reward, shall be guilty of an offence. ${ }^{3}$ The restriction extends to the keeping of a brothel defined as a "house or place that is kept for purposes of prostitution or for persons to visit for the purpose of having unlawful carnal intercourse or for any lewd or indecent purpose". ${ }^{4}$ The buying of sex has since 2012 also been criminalized, with the amendment of the Criminal Law (Sexual Offences) Act 32 of 2007 to extend penalties to anyone who unlawfully or intentionally engages in buying sex from another. ${ }^{5}$

Political debate surrounding sex work has centred on its criminalization or legalization, or variations of these two options, with four general policy approaches being adopted by countries worldwide. The first policy approach is the legalization of sex work, in which the selling and purchasing of sex is legal and regulated by government. This would include, for example, the licensing of brothels and specific zones where sex can be sold, with the Netherlands as a popular example. ${ }^{6}$ The second policy approach is decriminalization, in which all laws prohibiting and regulating sex work are removed and with little interference from government, such as in New Zealand. ${ }^{7}$ Third, is partial criminalization, in which only the client is held criminally liable, with Sweden as an example, and lastly, total criminalization, in which both the sex worker and client are held criminally liable, with South Africa and most of the states in the United States as examples. ${ }^{8}$

This difference in policy approach is inextricably linked to different feminist ideology on the topic, illustrating how feminist debate can influence political and legislative responses. Feminists have for decades debated the issue of how governments should respond to sex work, and it is evident that those

contd

exploitation and objectification. In this article, the term "sex work/sex worker" is used (except in reference to radical feminist arguments) as I follow the trajectory of support for the decriminalization of sex work by the South African government. The choice in terminology should not be seen as support/rejection for a specific theoretical approach.

2 South African Law Reform Commission (Project 107) Report on Sexual Offences: Adult Prostitution (2015; first published 2017).

3 Sec 20(1)(a) of the Sexual Offences Act 23 of 1957.

4 Secs 1 and 20(1)(a) of the Sexual Offences Act 23 of 1957.

5 Sec 11 of the Criminal Law (Sexual Offences) Act 32 of 2007.

6 K Beran "Revisiting the prostitution debate: Uniting liberal and radical feminism in pursuit of police reform" (2012) 30 Law and Inequality 19 at 21.

7 Ibid.

8 Ibid. 
responses can be traced to opposing theories concerning women's subordination and choice. ${ }^{9}$ The most prominent theoretical divide has been between radical and liberal feminist approaches with the tension being described as:

"The challenge of reforming prostitution laws poses an inescapable dilemma: to resist the commodification of women's sexuality, which requires circumscribing choices that some women themselves insist are voluntary, or to support the right of women to do work they say they want to do, at the cost of reinforcing male dominance." 10

Radical feminists view sex work as the ultimate form of male sexual oppression, with sex workers (women) as victims of this oppression and domination. ${ }^{11}$ Radical feminists prefer the term prostitute/prostitution as it stresses the exploitative nature of selling sex. ${ }^{12}$ In seeming opposition, liberal feminists argue that sex work is no different from any other form of work that women choose to do. ${ }^{13}$

Traditional feminist theory and debate on the topic have been starkly criticized, especially by sex workers themselves. African feminists have called for a more inclusive approach to regulating sex work that would acknowledge the various contexts in which sex is sold, specifically taking into account the circumstances of poor and marginalized sex workers. ${ }^{14}$

What remains key to understanding the development and implementation of a country's policy approach to sex work is the need to understand the different feminist ideologies on the topic. This article discusses the main feminist ideologies concerning sex work and how these ideologies have impacted South Africa's policy response to regulating sex work. The author calls for a more inclusive understanding of feminism, rather than a reliance on traditional theoretical preconceptions, including the need to acknowledge the importance of rights discourse in furthering political growth and protecting vulnerable groups. ${ }^{15}$

9 R Kruger "Sex work from a feminist perspective: A visit to the Jordan case" (2004) 20 South African Journal on Human Rights 138 at 140.

10 J Freeman "The feminist debate over prostitution reform: Prostitutes' rights groups, radical feminists and the (im)possibility of consent" (1989) 109 Berkeley Women's Law Journal 75 at 76 .

11 Beran "Revisiting the prostitution debate", above at note 6 at 38 .

12 VE Munro and M Della Giusta "The regulation of prostitution: Contemporary contexts and comparative perspectives" in VE Munro and M Della Giusta (eds) Demanding Sex: Critical Reflections on the Regulation of Prostitution (2008, Ashgate Publishing) 1 at 6.

13 Liberal feminists prefer the term sex work, which highlights women's agency and choice. J Oudshoorn "Introduction: prostitution, women's movements and democratic politics” in J Oudshoorn (ed) The Politics of Prostitution: Women's Movements, Democratic States and the Globalisation of Sex Commerce (2004, Cambridge University Press) 1 at 9.

14 I Thusi "Radical feminist harms on sex workers" (2018) 22 Lewis \& Clark Law Review 185 at 187; Munro and Della Giusta "The regulation of prostitution", above at note 12 at 225.

15 EM Schneider "The dialectic of rights and politics: Perspectives from the women's movement" (1986) 61 New York University Law Review 598. 


\section{FEMINIST RESPONSES TO SEX WORK}

Although there is no uniform feminist position on sex work and its regulation, the literature clearly diverges around two feminist approaches: radical and liberal feminism. ${ }^{16}$ Radical feminism views prostitution (the term sex work is rejected) as an extreme form of violence against women and fostered through the exploitation of women's bodies. ${ }^{17}$ Most radical feminists argue for the abolition of prostitution through criminalization of the act of buying, thus protecting women from its exploitation. ${ }^{18}$ Selling sex is not seen as incidental, but endemic within a patriarchal culture that promotes women's sexuality as a commodity. ${ }^{19}$

Liberal feminists, on the other hand, regard sex work as a form of legitimate labour that women can and do choose to engage in (hence the term sex work). ${ }^{20}$ This falls within the general liberal feminist acceptance "of the ideal of autonomous individuals who are free to make choices that benefit themselves". ${ }^{21}$ Most liberal feminists support the decriminalization of sex work, as this would address vulnerabilities such as police brutality and harassment and would place sex workers within the protective ambit of labour law regulation. ${ }^{22}$

Radical feminists criticize the liberal reliance on individualism and choice, and argue that the focus on the "self" disregards the context in which women are prostituted or "choose" so-called prostitution as a profession. ${ }^{23}$ Radical feminists argue that, when confronted with extreme poverty, women are left with little choice but to prostitute themselves, and that prostitution is not a naturally occurring opportunity, but socially constructed with prostitutes (women) as the ultimate victims of a patriarchal society. ${ }^{24}$ MacKinnon, as a radical feminist, argues that women's ability to consent is always constrained, including the "so-called" choice to prostitute oneself. ${ }^{25}$

16 Beran "Revisiting the prostitution debate", above at note 6 at 22 .

17 LA Jeffrey "Canadian sex work policy for the 21st century: Enhancing rights and safety, lessons from Australia” (2009) 3 Canadian Political Science Review 57 at 60; J Comte "Decriminalization of sex work: Feminist discourses in light of research" (2014) 18 Sexuality and Culture 196 at 198.

18 M Tyler "Theorizing harm through the sex of prostitution" in M Coy (ed) Prostitution, Harm and Gender Inequality: Theory, Research and Policy (2012, Ashgate Publishing) 87 at 88.

19 F Bettio, M Della Giusta and ML Di Tommaso "Sex work and trafficking: Moving beyond dichotomies" (2017) 23 Feminist Economics 1 at 2.

20 Munro and Della Giusta "The regulation of prostitution", above at note 12 at 1.

21 K Van Marle and E Bonthuys "Feminist theories and concepts" in E Bonthuys and C Albertyn (eds) Gender, Law and Justice (2007, Juta) 15 at 32.

22 South African Law Reform Commission Issue Paper 19 (Project 107) Sexual Offences: Adult Prostitution (2002) 58.

23 S Jeffreys "Beyond 'agency' and 'choice' in theorizing prostitution" in M Coy (ed) Prostitution, Harm and Gender Inequality: Theory, Research and Policy (2012, Ashgate Publishing) 69 at 75.

24 Ibid.

25 CA MacKinnon "Trafficking, prostitution and inequality" (2011) 46 Harvard Civil Rights Civil Liberties Law Review 271 at 292. 
Radical feminist arguments have also been criticized, with some critics arguing that not all consent is constrained but is instead structural and changeable, and that an individual's ability to participate in consent should be acknowledged. ${ }^{26}$ Further criticism relates to the fact that radical feminists often view the trafficking of women for sexual exploitation as the ultimate form of prostitution, a view that strengthens support for criminalizing the buying of all sex. ${ }^{27}$ This radical feminist standpoint has found an unlikely soundboard in American evangelical Christian organizations that have created a strong anti-trafficking movement, which, together with influence in government(s), have given rise to what Elizabeth Bernstein has dubbed "carceral feminism". ${ }^{28}$ Carceral feminism calls for harsh criminal penalties against traffickers, sex workers and clients to protect and provide justice to (all) women. ${ }^{29}$ For carceral feminists and the anti-trafficking movement, victims need to be saved, and criminals punished. ${ }^{30}$

Cojocura describes the media attention generated by the anti-trafficking movement as a spectacle in which female misery and degradation are the main attraction, focusing on images of poverty, coercion, violence and, of course, sex. ${ }^{31}$ The unfortunate consequence of this "spectacle" is a perception of migration for possible sexual commerce as sex trafficking, and an interpretation of women's unregulated movement across borders as sexual and economic exploitation. ${ }^{32}$ The stereotypical equation of human trafficking with sexual exploitation has enabled a single framework of victimhood that has made the majority of migrant exploitation go unseen. ${ }^{33}$

Sex workers and sex worker advocacy groups have been vocal in rejecting traditional feminist debates concerning sex work and victim typology, arguing that these interpretations do not account for their experience. ${ }^{34}$ With vocal sex worker activism and an increasing focus on African feminism(s), there

26 Freeman "The feminist debate over prostitution reform", above at note 10 at 97.

27 CA Jackson "Framing sex worker rights: How U.S. sex worker rights activists perceive and respond to mainstream anti-trafficking advocacy" (2016) 59 Sociological Perspectives 27 at 30; R Marshall "Sex workers and human rights: A critical analysis of laws regarding sex work" (2016) 23 William E Mary Journal of Race, Gender, and Social Justice 47 at 64.

28 E Bernstein "Militarized humanitarianism meets carceral feminism: The politics of sex, rights, and freedom in contemporary antitrafficking campaigns" (2010) 36 Journal of Women in Culture and Society 45 at 46.

29 M Smith and J Mac Revolting Prostitutes: The Fight for Sex Workers' Rights (2020, Verso) 16.

30 L Augustin "Forger victimisation: Granting agency to migrants" (2003) 46 Development 61 at 61 .

31 C Cojocaru "Sex trafficking, captivity, and narrative: Constructing victimhood with the goal of salvation” (2015) 39 Dialectical Anthropology 183 at 184

32 Ibid.

33 S Tomkinson "The multiplicity of truths about human trafficking: Beyond "the sex slave" discourse" (2012) 7 CEU Political Science Journal 50 at 52.

34 Thusi "Radical feminist harms on sex workers", above at note 14 at 187; Munro and Della Giusta "The regulation of prostitution", above at note 12 at 6 . 
has been growing recognition for the need to transcend the victim/agent dichotomy and to acknowledge the complexity of selling sex. ${ }^{35}$

Mgbako argues that rescue politics and the "protection" of sex workers through criminal law is the very source of their extreme vulnerability and abuse. ${ }^{36}$ She argues that illegality pushes sex work underground, which provides sex workers with no access to labour rights, health care services and other social and economic safety nets. ${ }^{37}$ She further argues that criminal law grants the police and state agents impunity in taking advantage of sex workers in refusing them access to justice when clients turn violent or in exploiting them for sexual favours. ${ }^{38}$ Furthermore, third-party managers in brothels, massage parlours and indoor venues knowingly exploit sex workers as there is no labour protection available, thus creating a cycle of violence and impunity. 39

Importantly, Mgbako contends that if feminist arguments are supported that characterize all sex work as inherently violent, the actual violence that sex workers suffer will go unnoticed:

\begin{abstract}
"If we say that sex workers are incapable of consenting to the provision of sexual services for pay, and it is all tantamount to paid rape, then a sex worker who is actually raped by a client is invisible. If we insist that a sex worker is "selling her body", when in fact she still retains her body after the exchange and instead is providing a service, then we remove her from the world of labor - with all its potential protections - and banish her to the realm of sexual moralism." ${ }^{40}$
\end{abstract}

For Mgbako, the human rights abuse of sex workers across the African continent has a single origin, which is the criminalization of sex work and ensuing stigma. ${ }^{41}$ She advocates the decriminalization of sex work, which would grant sex workers access to the rights and recourse had by other workers and individuals. Richter, echoing the need for an African perspective to sex work, also supports decriminalization, on the grounds that criminalization makes sex workers more vulnerable to violence, coercion, stigma and serious illness. ${ }^{42}$

Despite a growing acknowledgment that traditional feminist theory does little to protect the rights of actual sex workers, the policies of most countries

35 CA Mgbako and LA Smith "Sex work and human rights in Africa" (2010) 33 Fordham International Law Journal 1178 at 1179.

36 CA Mgbako "The mainstreaming of sex workers' rights as human rights" (2020) 43 Harvard Journal of Law \& Gender 91 at 106.

37 CA Mgbako To Live Freely in This World: Sex Worker Activism in Africa (2016, NYU Press) 52.

38 Ibid.

39 Ibid.

40 Id at 58.

41 CA Mgbako "The case of decriminalisation of sex work in South Africa" (2013) 44 Georgetown Journal of International Law 1423 at 1426.

42 M Richter "Sex work as a test case for African feminism" (2012) 2 Buwa: A Journal on African Women's Experiences 62 at 66. 
are still associated with support for either radical or liberal feminist arguments. ${ }^{43}$ Sweden's policy response is upheld as a progressive radical feminist approach to regulating sex work. ${ }^{44}$ Sweden criminalizes only the buying of sex (clients) and provides sex workers with support services in order to help them exit the trade. ${ }^{45}$ Although the Swedish law is gender neutral, its intention is to address gender inequality by challenging patriarchy and the acceptance that male sexual entitlement is inevitable. ${ }^{46}$ The goal of the Swedish model is not to regulate sex work, but to eradicate sex for pay, with the assumption that a reduction in the amount of paid sex would also mean a reduction in the amount of trafficking for sexual exploitation. ${ }^{47}$

Although the Swedish government did report a supposed decline in the selling of sex on the streets, there has been little evidence to support that claim. ${ }^{48}$ Many argue that the policy has simply driven sex work underground as clients are fearful of being prosecuted. ${ }^{49}$ This outcome would be problematic, as sex workers would then have limited control over a risky situation and be less likely to access care facilities when needed. Beran argues that Sweden's policy response should instead be viewed within the context of a well-established and prosperous welfare state that is able to provide social services to sex workers in order to ensure that they are able to exit the industry successfully. ${ }^{50}$

Several exit strategies and so-called "rehabilitation" programmes have been implemented on the African continent, but with little success in providing actual support to sex workers. ${ }^{51}$ Skills-training workshops include classes in, for example, sewing, candle making and beading. These alternative livelihoods, however, embrace stereotypical preconceptions of "women's work" and are inherently low paid. ${ }^{52}$ Mgbako argues that African sex workers who enter the industry choose sex work in order to escape exactly that type of lowpaid work that is touted as an alternative, and that the decisions they make, based on economics, are "utterly rational in light of the financial pressures they face" ${ }^{53}$ If alternative livelihood programmes do not ensure a superior economic choice, then these programmes leave the women more financially vulnerable than they were before they entered them.

43 Jeffrey "Canadian sex work policy for the 21st century", above at note 17 at 60 .

44 Marshall "Sex workers and human rights", above at note 27 at 60.

45 Ibid.

46 J Erikson "The various 'problems' of prostitution - A dynamic frame analysis of Swedish prostitution policy" in M Coy (ed) Prostitution, Harm and Gender Inequality: Theory, Research and Policy (2012, Ashgate Publishing) 159 at 159.

47 Bettio, Della Giusta and Di Tommaso "Sex work and trafficking", above at note 19 at 2.

48 A Jordan "The Swedish law to criminalise clients: A failed experiment in social engineering (2012) Issue paper 4" Centre of Human Rights \& Humanitarian Law 1.

49 Marshall "Sex workers and human rights", above at note 27 at 62.

50 Beran "Revisiting the prostitution debate", above at note 6 at 54 .

51 Mgbako "To live freely in this world", above at note 37 at 163.

52 Ibid.

53 Id at 164. 
In adopting a policy of decriminalization, New Zealand is seen as a primary example of a country with the most liberal sex work policy of all. New Zealand acknowledges sex work as service work, and allows sex workers to operate under the same employment and legal rights as any other occupation, with no specific regulation except within the existing legal framework. ${ }^{54} \mathrm{New}$ Zealand prides itself that its policy response was developed in full consultation with sex workers, and argues that it is therefore responsive and workable for those women actually involved in sex work. ${ }^{55}$ The most positive outcome of New Zealand's policy framework has been described as the ability to talk frankly about sex work, which enables sex workers to negotiate safer sex and also access services without fear of them or their clients being arrested. ${ }^{56}$ One of the most widely touted arguments against decriminalization is that it would lead to an increase in sex work and trafficking. To date, New Zealand has reported no evidence that this is the case but, despite that country's positive experience, few other countries have followed suit in adopting a policy of complete decriminalization. ${ }^{57}$ Abel argues that this could be credited to morality politics and anti-trafficking lobbying, in that decriminalization is seen as condoning the trafficking of women for sexual exploitation. ${ }^{58}$

Many European countries, with the Netherlands as the prominent example, have opted to legalize and regulate sex work, supporting the liberal argument that sex work is work. Although the policy response of legalization and regulation has been commended for lessening the strain on the criminal justice system, sex workers argue that this system still marginalizes and effectively criminalizes those who do not fulfil the various bureaucratic requirements. ${ }^{59}$ To this extent, Bingham argues that a regulatory framework provides countries with a controlled means of selling women's sexual services whilst still limiting sex workers' choices and self-control. ${ }^{60}$ It is also argued that the indoor sex industry promoted through legalization does little to secure the safety of sex workers, with the bulk of the profit going to pimps and brothel owners. ${ }^{61}$

Australia's response to sex work indicates that there might be more than one policy response possible as the country has legalized and regulated sex work in certain states and decriminalized it in others. ${ }^{62}$ Despite the different

54 GM Abel "A decade of decriminalisation: Sexwork 'down under' but not underground" (2014) 14 Criminology and Criminal Justice 580 at 581.

55 Ibid.

56 Id at 586.

57 Mgbako "The case for decriminalisation in South Africa", above at note 41 at 1437.

58 Id at 587.

59 Marshall "Sex workers and human rights", above at note 27 at 62.

60 N Bingham "Nevada sex trade: A gamble for the workers" (1998) 10 Yale Journal of Law and Feminism 69 at 93.

61 M Farley "Prostitution harms women even if indoors" (2005) 11 Violence Against Women 950 at 955, Jeffrey "Canadian sex work policy for the 21st century", above at note 17 at 75. Jeffrey "Canadian sex work policy for the 21st century", above at note 17 at 61 . 
policies, Australia has stressed its commitment to support women who sell sex and also stated that its reform of the industry is ongoing and responsive to the needs of the women involved. ${ }^{63}$ The full criminalization of sex work, such as in South Africa, is viewed as the most problematic policy approach of all to sex work. Mgbako argues that laws and policies that criminalize sex work deeply marginalize sex workers and create unsafe working conditions. ${ }^{64}$

Although decriminalization is not widely supported, many argue that it is the best policy option for protecting current sex workers in the industry. Richter states that, even if one supports a radical feminist approach and believes that sex work is deeply oppressive to all women, one still has to acknowledge that criminal law will not completely eradicate the sex industry. ${ }^{65}$ The discussion that follows focuses on the SALRC's investigation concerning sex work and questions the influence of traditional feminist thought in creating contradictory messages concerning the South African government's policy response.

\section{SOUTH AFRICA AND SEX WORK: MOVING TOWARDS A POLICY OF DECRIMINALIZATION?}

As stated above, both the selling and buying of sex is criminalized in South Africa. The selling of sex has been criminalized for some time under the Sexual Offences Act 23 of 1957, ${ }^{66}$ with the buying of sex only becoming criminalized after the Constitutional Court case of $S v$ Jordan (Jordan), ${ }^{67}$ and with the amendment of the Criminal Law (Sexual Offences) Act 32 of 2007. Despite strict legislation that criminalizes the buying and selling of sex, decriminalization has been on the government's agenda for some time.

In 1996, the Gauteng Cabinet Committee on Safety and Security and Quality of Life was requested to draft a policy document on sex work, focusing on the way in which sex work was policed in the province. ${ }^{68}$ The document recommended the decriminalization of sex work, and found that police resources could be better spent elsewhere. ${ }^{69}$ Shortly after the release of the document, the Department of Justice and Constitutional Development's Gender Policy

\section{Id at 69.}

64 Mgbako "To live freely in this world", above at note 37 at 5.

65 Richter "Sex work as a test case for African feminism", above at note 42 at 66.

66 Sec 20(1)(a) of the Sexual Offences Act states: "Any person who has unlawful carnal intercourse, or commits an act of indecency, with any other person for reward, shall be guilty of an offence. Section 2 of the act states that any person who keeps a brothel shall be guilty of an offence, and section 3 provides that certain persons would be deemed to keep a brothel including '(b) any person who manages or assists in the management of any brothel; (c) any person who knowingly receives the whole or any share of any moneys taken in a brothel'."

$67 S v$ Jordan and Others (Sex Workers Education and Advocacy Task Force and Others as Amici Curiae) 2002 (6) SA 642 (CC).

68 SALRC Issue Paper 19, above at note 22 at 36.

69 JM Wojcicki "The movement to decriminalize sex work in the Gauteng province, South Africa, 1994-2002” (2003) 46 African Studies Review 83 at 87. 
Statement stated that the decriminalization of sex work was an international obligation in terms of the Convention on the Elimination of All Forms of Discrimination Against Women (CEDAW), and was an option that should be seriously considered by South Africa. ${ }^{70}$ At the same time, the SALRC was tasked with its own investigation in reforming this area of law, with a project that started as an investigation into sexual offences by and against children, but was later expanded into a project concerning sexual offences against adults, including a project on adult sex work. ${ }^{71}$

The SALRC released three reports on the project, with its research spanning over a decade. The reports follow the working method of the SALRC in first publishing an issue paper that outlines the problems encountered in a specific area of law and then inviting submissions on possible solutions. ${ }^{72}$ Thereafter, a discussion paper is drafted that includes responses to the issue paper and further research on the topic. A discussion paper usually concludes with a proposal for reform that can include a draft Bill on the topic. ${ }^{73}$ Responses to the discussion paper and additional research form the basis of the final report that is submitted to the Minister of Justice and Constitutional Development for his/her consideration and implementation.

\section{The SALRC issue paper: 2002}

The 2002 SALRC issue paper was a lengthy and thorough investigation on adult sex work in the country (226 pages in length). The paper provided a historical overview of sex work and included an analysis of liberal and radical feminist views on the topic. It further explored the international human rights framework and other country policy responses, including those of Sweden, the Netherlands, Germany, Thailand, New Zealand, Australia and, in the USA, the states of Nevada and San Francisco. ${ }^{74}$

Separate chapters of the paper were dedicated to sex work and HIV/Aids and to sex work and trafficking. ${ }^{75}$ In relation to sex work and trafficking, the report recommended that South Africa consider the adoption of separate legislation to address human trafficking. ${ }^{76}$

70 The Department of Justice and Constitutional Development's Gender Policy Statement (1999) at 27-28 available at: <https://justice.gov.za/policy/1999-GenderPolicyStatement. pdf> (last accessed 17 August 2020).

71 SALRC Issue Paper 19, above at note 22 at 27-28.

72 South African Law Reform Commission "Objects, constitution and function" available at: <http://www.justice.gov.za/salrc/objects.htm> (last accessed 17 August 2020).

73 Ibid.

74 SALRC Issue Paper 19, above at note 22 at 5. It should be noted that the discussion of New Zealand's sex work policy referred to the policy framework before the adoption of the Prostitution Reform Act of 2003 when sex work was still partly criminalized.

75 SALRC Issue Paper 19, above at note 22 at chapters 8 and 9 respectively.

76 Id at 207. The South African government has since adopted separate legislation that regulates human trafficking, namely the Prevention and Combating of Trafficking in Persons Act 7 of 2013. 
The last chapter of the issue paper discussed the different sex work policy options available, which included criminalization, partial criminalization, decriminalization or legalization. To assist with the drafting of its discussion paper, the SALRC posed three questions to which it invited responses. First, if criminalization was considered as the best policy option, would criminalization be total or partial? If partial criminalization was considered, who would be held liable, the seller or the buyer, and how would concerns regarding the current system of criminalization be addressed ${ }^{77}$ The second question related to legalization and the regulations that would be necessary if this proved to be the best policy option. For example, what would be required in relation to licensing, zoning, health screening and testing? ${ }^{78}$ Lastly, if decriminalization were to be considered, would any other acts relating to sex work still have to be criminalized, for example procurement? Would further by-laws be required, and should specific measures be enacted, for example in promoting safe-sex practices? ${ }^{79}$

The issue paper noted that there was pending litigation before the Constitutional Court regarding the decriminalization of sex work, and that the SALRC would not indicate its support for a specific policy option pending the outcome of the litigation. ${ }^{80}$

\section{Litigating for sex work reform: S v Jordan 2002}

The case of Jordan was heard by the Constitutional Court in early 2002. Jordan, a brothel owner, together with two of her employees, was arrested for contravening the Sexual Offences Act. Jordan was charged with keeping a brothel, the receptionist with assisting in the management of a brothel, and a sex worker for committing an act of indecency for reward with a policeman (parties collectively referred to as Jordan). Jordan argued that the relevant sections of the Sexual Offences Act were unconstitutional as they infringed their constitutional rights to privacy, equality and freedom of trade. ${ }^{81}$ It should be noted that when the case was heard, only the act of selling sex was criminalized under the terms of the Sexual Offences Act.

The High Court found that the relevant sections of the Act were unconstitutional, except for the sections in relation to brothel-keeping. ${ }^{82}$ The declaration of invalidity was then sent to the Constitutional Court for confirmation, and Jordan appealed the High Court's refusal to set aside the brothel provisions. ${ }^{83}$

77 SALRC Issue Paper 19, above at note 22 at 213.

78 Id at 222.

79 Id at 226.

80 Id at 5 .

81 See secs 14, 9 and 22 of the Constitution of the Republic of South Africa, 1996 (the Constitution) respectively.

$82 S$ v Jordan and Others 2002 (1) SA 797 (T) (Jordan HC).

83 The Constitution, sec 167(5): "The Constitutional Court makes the final decision whether an Act of Parliament, a provincial Act or conduct of the President is constitutional, and 
The litigation was controversial, as advocacy groups and nongovernmental organizations felt that both Jordan's circumstances and the factual scenario of the case were not representative of the broader sex work trade, specifically that of outdoor sex workers. ${ }^{84}$ Concerned organizations, including the Commission for Gender Equality (CGE) and the Sex Workers Education and Advocacy Taskforce (SWEAT), in collaboration with the Centre for Applied Legal Studies and the Reproductive Health Research Unit, participated as amici curiae in order to provide the Constitutional Court with contextual evidence to ensure that the voices of all sex workers were represented.

In the Constitutional Court, Jordan again emphasized that the legislation curtailed sex workers' constitutional rights. In relation to the right to equality, Jordan argued that sex workers were unfairly discriminated against on the basis of gender because only the selling of sex (mostly by women) was criminalized and not the buying of sex (mostly by men). ${ }^{85}$

The state, on the other hand, emphasized radical feminist arguments and focused on the harm caused by selling sex and the fact that sex work ultimately degraded women and commodified their sexuality. ${ }^{86}$ The state further argued that a range of social ills inherent to sex work, including violent physical abuse, encouragement of trafficking in women and children, the spread of sexually transmitted diseases, drug abuse and crimes such as bribery, corruption, drug trafficking, assault, public nuisance, robbery and even murder, would best be served by prohibition rather than by decriminalization and/or regulation. ${ }^{87}$ The state countered Jordan's equality argument by stating that prohibition is gender neutral and therefore impacts both female and male sex workers. ${ }^{88}$

The Constitutional Court found against the decriminalization of sex work, with the majority of the court (with Chaskalson CJ, Kriegler J, Madala J, Du Plessis AJ and Skweyiya AJ concurring) supporting the state's arguments:

"And if there is any discrimination, such discrimination can hardly be said to be unfair. The Act pursues an important and legitimate constitutional purpose, namely to outlaw commercial sex. The only significant difference in the proscribed behaviour is that the prostitute sells sex and the patron buys

contd

must confirm any order of invalidity made by the Supreme Court of Appeal, the High Court of South Africa, or a court of similar status, before that order has any force." RB Cowan "The Women's Legal Centre during its first five years" (2005) Acta Juridica 273 at 287.

85 CR Jansen and N Janse van Nieuwenhuizen "Written submissions of the applicant" Case number: CCT 31/01 paras 29-32.

86 Id, paras 8-12.

87 W Trengove (SC) and A Cockrell "Written submissions of the State" Case number: CCT 31/01 para 5 .

Ibid. 
it. Gender is not a differentiating factor. Indeed, one of the effective ways of curbing prostitution is to strike at its supply." ${ }^{19}$

The case dealt a blow to the consultative framework that was established by sex worker advocacy groups, NGOs and government in reforming the sex industry. Sex work reform and the possibility of decriminalization fell off the legislative agenda for a number of years.

\section{The SALRC discussion paper: 2009}

In 2009, the SALRC discussion paper and second report on adult sex work was released. The report was again a lengthy analysis (over 300 pages) of the current legal framework, the social and economic context of sex work, and a comparative analysis of policy directives in other African countries, as opposed to only Western counterparts.

The discussion paper, which was able to reflect on the court judgment in Jordan and the input received in response to the issue paper, succeeded in identifying two workable policy options: continued criminalization or total decriminalization.

Continued criminalization was supported by individuals and organizations that endorsed radical feminist views as well as those who were opposed to decriminalization based on moral and religious grounds. ${ }^{90}$ To this extent, individuals debated that sex work undermined the dignity of sex workers and made sex objects out of women, with a Christian group arguing that sex work negated morality and degraded neighbourhoods, leading to the breakdown of family structures. ${ }^{91}$ Doctors for Life International argued that sex work increased transmittable diseases such as HIV, and it therefore supported criminalization as a way of reducing sex work and eliminating the industry altogether. ${ }^{92}$

Decriminalization was supported by individuals and organizations who advocated a rights-based approach to the regulation of sex work and focused on the disproportionate impact criminalization had on poor, mostly black, street sex workers. ${ }^{93}$ Proponents of decriminalization argued that decriminalization would provide sex workers with better access to health care services and access to a regulated labour market. ${ }^{94}$

89 Jordan, above at 67, para 15 (footnotes omitted).

90 South African Law Reform Commission Discussion Paper 0001 (Project 107) Sexual Offences: Adult Prostitution (2009) at 182.

91 Id at $177-78$.

92 Id at $178-84$.

93 Id at 188.

94 Ibid. Decriminalization was supported in a joint submission by the Centre for Applied Legal Studies, SWEAT, the Women's Legal Centre (WLC), People Opposing Women Abuse, the Legal Resources Centre, Tshwaranang Legal Advocacy Centre to end Violence Against Women, the Commission on Gender Equality (CGE), the Gay and Lesbian Coalition and Sexual Harassment Education Project. 
Considering all the arguments, the SALRC concluded that the current law of criminalization did not effectively regulate sex work in South Africa as it contributed to sex workers' vulnerability, exploitation and abuse. ${ }^{95}$ The SALRC did not directly support decriminalization, but again requested further input regarding the four available policy options that would assist the Commission in drafting its final report and recommendation to the minister. ${ }^{96}$ However, after the release of the issue paper, it seemed as if the SALRC process had been halted, with a six-year delay in drafting the final report (2015) and a further two-year delay in publishing it (2017). ${ }^{97}$ The delay may be ascribed to the fact that the SALRC was without any commissioners between 2011 and 2013, but even taking this into consideration, the delay was unreasonably long and without any real explanation as to why that would have been. ${ }^{98}$

With the SALRC seemingly leaning towards decriminalization in the discussion paper, organizations and advocacy groups continued to lobby for decriminalization and sex workers' rights protection. In 2010 SWEAT, supported by the Women's Legal Centre, approached the Labour Appeal Court (LAC) in Kylie $v$ CCMA and Others to gain protection for a sex worker who was apparently unfairly dismissed by the massage parlour where she worked. ${ }^{99}$

The LAC found that although it could not sanction sex work, its criminalization could not derogate sex workers' constitutional rights, including the right to fair labour practice, and that the Commission for Conciliation, Mediation and Arbitration (CCMA) did have the necessary jurisdiction to hear the matter, which the initial court found it had lacked. Kylie was a positive indication that organizations did not give up on litigation after Jordan to protect sex workers' rights.

\section{The great divide: full criminalization versus decriminalization}

In 2012, the Sexual Offences Act was amended to explicitly criminalize the buying of sex (clients). ${ }^{100}$ Considering the state's arguments in $S v$ Jordan,

95 SALRC Discussion Paper 0001, above at note 92 at 226.

96 Id at 226. The questions in relation to each of the four policy options are set out on pages 233-49 of the discussion paper.

97 SALRC Report Project 107, above at note 2.

98 Multi-Party Women's Caucus “Sex work decriminalisation: Commission on Gender Equality, SWEAT, South African Law Reform Commission, Department of Justice, Parliamentary Legal Services" (17 August 2016) available at: < https://pmg.org.za/co mmittee-meeting/23084/> (last accessed 18 August 2020).

99 Kylie $v$ CCMA and Others 2010 (4) SA 383 (LAC).

100 The Criminal Law (Sexual Offences and Related Matters) Amendment Act 6 of 2012 amended sec 11 of the Criminal Law (Sexual Offences Act) 32 of 2007, which now states:

"A person ('A') who unlawfully and intentionally engages the services of a person 18 years or older ('B'), for financial or other reward, favour or compensation to B or to a third person ('C') - 
the amendment was hardly surprising, however the extent to which it has been implemented is uncertain as no discernible statistics are available to indicate how many buyers have been held liable under the terms of the amended legislation.

Shortly after the amendment, the CGE reconfirmed its support for the total decriminalization of sex work. In a short publication, the CGE analysed the difference between liberal and radical feminist arguments and the different policy options available to countries. ${ }^{101}$ The publication focused on New Zealand, where decriminalization had been successfully adopted, and with the finding of no discernible increase in sex work or human trafficking since decriminalization had been introduced. ${ }^{102}$ The CGE warned against common misconceptions regarding sex work, and also advised that South Africa's sex work policy response needed to respect and give effect to sex workers' constitutional rights.

Despite the Constitutional Court's restrictive decision in $S v$ Jordan and legislation criminalizing the selling and buying of sex, the South African government, through various initiatives and parliamentary discussions, publicly supported the decriminalization of sex work. President Ramaphosa (then Deputy) commented, during the launch of the South African National Sex Worker HIV Plan in March 2016, that there was a definite need to respond to the legal, social, health and welfare dimensions of sex workers in a comprehensive and consistent manner. ${ }^{103}$ He further stated that government had to review the legal status of sex work in order to ensure a balance between the rights of individuals and that of society.

In August 2016, the Multi-Party Women's Caucus in parliament (MPWC) held a session to discuss the decriminalization of sex work and heard submissions from various stakeholders on the topic. ${ }^{104}$ The CGE, SWEAT and the Sisonke Sex Workers Movement reiterated their commitment to decriminalization and raised the concern that the final SALRC report was still outstanding seven years after the release of the issue paper.

contd

(a) For the purpose of engaging in a sexual act with B, irrespective of whether the sexual act is committed or not; or

(b) By committing a sexual act with $\mathrm{B}$, is guilty of engaging the sexual services of a person 18 years or older. The imposition of penalties in respect of this section is left to the discretion of the courts."

101 Commission for Gender Equality "Commission for Gender Equality: Position on sex work” (2013) available at: <http://www.cge.org.za/index.php?option=com_docman\&tas k=doc_download\&grid=223\&Itemid=> (last accessed 18 August 2020).

102 Id at 6 .

103 The Presidency "Deputy President Ramaphosa: Launch of the South African National Sex Worker HIV plan" (11 March 2016) available at: <https://www.gov.za/speeches/addressdeputy-president-cyril-ramaphosa-launch-south-african-national-sex-worker-hiv-plan> (last accessed 18 August 2020).

104 Multi-Party Women's Caucus, above at note 98 at 80. 
The SALRC, present at the sitting, commented that the report, with its final recommendation, was already before the minister and that its public release was imminent. The SALRC attributed the delay to the fact that it had had no commissioners for some time, and that it was obliged to consider lengthy submissions in response to the issue paper. The SALRC also claimed that the final report had been submitted to the Department of Justice and Constitutional Development in August 2015, and with that department's own internal deliberation further delaying the release.

The SALRC submissions at the sitting provided some insight into what its final recommendation would be. The SALRC noted that government was not constitutionally obligated to change the existing law because the legislation had already passed constitutional scrutiny in $S v$ Jordan, and that any further decision would be a pure policy directive that had to be carefully executed. The SALRC cautioned against using New Zealand as a benchmark for decriminalization, for the reason that the context was far removed from that of South Africa's, and that any radical shift in the legislative framework ought not to result in rendering sex workers more vulnerable. The SALRC further cautioned that decriminalization would not necessarily address other illegal activities linked to sex work, such as violence perpetrated against sex workers, which reflected the state's arguments in $S v$ Jordan.

\section{The SALRC's final report}

The SALRC's final report on sex work was released on 26 May 2017 with two suggested draft Bill options. The first Bill supported partial criminalization, not criminalizing the conduct of sex workers but criminalizing, for example, soliciting and sexual acts in a public place (similar to the Swedish position). The second, and the Bill option preferred by the SALRC, recommended continued criminalization of all sex work (selling and buying), with an option for sex workers to divert from the criminal justice system if there were to be a transgression. ${ }^{105}$ The findings were disappointing as the South African government had previously seemed receptive to supporting decriminalization.

When reading the SALRC final report, one is confronted with badly drafted arguments, which, although seemingly grounded in radical feminist theory, are not supported by any theoretical reference or discussion. The SALRC's premise for supporting continued criminalization is based on the concept of exploitation, and that decriminalization would increase exploitative practices such as child prostitution and human trafficking:

"The Commission believes that in South Africa, prostitution in its many guises - albeit "voluntary" - clearly exploits women and men who provide sexual services. Even ostensibly self-chosen or self-initiated involvement in prostitution is a symptom of the inequality and marginalisation that are a daily experience 
of many impoverished people, especially women. The exploitation of a person's lack of alternatives does not amount to a considered exercise of that person's own choice. Prostitution in South Africa can also be viewed as an aspect of male violence against women and children. South Africa is grappling with high levels of violence against women, with sexual assault and intimate partner violence contributing to increased risks for HIV infection. Changing the legislative framework could create an extremely dangerous cultural shift juxtaposed against the high numbers of sexual crimes already committed against women. Women would be considered even more expendable than at present. Furthermore, the Commission believes that legalising prostitution would increase the demand, locally and internationally, for more prostituted persons, and would foster a culture that normalises prostitution and sexual coercion. Overall, the Commission believes that due to the systemic inequality between men and women in South Africa, any form of legalisation will not magically address the power imbalance between the buyer and the prostitute, or the demand by buyers for unsafe or high-risk sex."106

In light of the above, the SALRC did not view decriminalization as a suitable policy option or partial criminalization either, as it argued that South Africa, unlike Sweden, does not have a wealthy welfare state. ${ }^{107}$ The Commission further argued that full criminalization would significantly reduce the demand for paid sexual services; however, no evidence was provided that this is the case under the current system of criminalization. ${ }^{108}$ The final report was drafted in seeming isolation, with almost no crossreferencing to the previous two SALRC reports or with any theoretical justification for the findings made.

In response to the SALRC report, parliament's Multi-Party Women's Caucus (MPWC) hosted a sex work summit in early 2018 in order to hear stakeholders' responses and their input into the findings of the report. ${ }^{109}$ The report was not well received, and most stakeholders argued that the SALRC did not engage with or consider inputs from sex workers themselves. The summit findings were tabled and discussed in parliament during May 2018, with the MPWC finding that there was a need for further deliberation in order to ensure proper public participation before government could consider an adapted policy response. ${ }^{110}$ The Caucus suggested that public participatory

106 Id, para 43.

107 Id, para 44.

108 Id, para 55.

109 Multi-Party Women's Caucus “Multi-Party Women's Caucus to deliberate further on decriminalisation of sex work" available at: <https://www.parliament.gov.za/news/mul ti-party-womens-deliberate-further-decriminilisation-sex-work> (last accessed 18 August 2020).

110 Multi-Party Women's Caucus “SALRC adult prostitution report: Summit recommendations; IEC initiatives on gender quotas for 2019 elections” (30 May 2018) available at: <https://pmg.org.za/committee-meeting/26543/> (last accessed 18 August 2020). 
meetings be held in all nine provinces, and with a view to obtaining as many views and inputs as possible. It further noted that the SALRC did little to clarify the findings of the report, and that considering the time lapse in drafting the final report, more information was now required as the report had disregarded developments in the area of sex work policy reform and gender-based violence during the intervening period. ${ }^{111}$

Despite the MPWC's findings, there has been little traction in its implementation, with no public participatory meetings held to date. In March 2019, at the launch of the Declaration Against Gender-based Violence and Femicide, President Ramaphosa cited the need to develop a policy on the decriminalization of sex work, but since then there has been little detail or any suggested time frame as to when government would prioritize such a policy initiative. ${ }^{112}$

After the South African general election in 2018, the MPWC was reconstituted, and at its first meeting in 2019 it was noted that the project on the decriminalization of sex work would continue under its term. Again, there has been no traction regarding sex work policy reform, or any implementation of suggestions about further public participation, as requested by the previous Caucus.

In August 2019, after conducting research in four provinces, Human Rights Watch released a research report arguing for the decriminalization of sex work in South Africa. ${ }^{113}$ The report found that almost three-quarters of sex workers had been arrested more than once, and that a broad pattern existed of police harassment, including extortion, coercive sex and the use of derogative language towards sex workers. The report further found that criminalization remained one of the main barriers to sex workers having access to proper health care services, despite a policy document that ensured sex workers' access to such services. ${ }^{114}$ Thus, it confirms the corrupt nature of policing sex work in South Africa, and also states that the police extort money not only from the sex workers themselves, but also from their clients in return for not arresting them. ${ }^{115}$

The SALRC final report remains problematic because it counters the government's commitment to decriminalization and makes it uncertain whether the suggested public participation on the report's content would be of any further

111 Id at 2.

112 The Presidency "President Cyril Ramaphosa: Launch of declaration against gender-based violence and femicide and opening of Booysens Magistrate's Court” (28 March 2019) at 2 available at: <https://www.gov.za/speeches/president-cyril-ramaphosa-launch-declaratio n-against-gender-based-violence-and-femicide-and> (last accessed 18 August 2020).

113 Human Rights Watch "Why should sex work be decriminalised in South Africa" (2019) available at: <https://www.hrw.org/sites/default/files/report_pdf/southafrica0819_ web_0.pdf> (last accessed 18 August 2020).

114 Id at 14

115 Thusi "Radical feminist harms on sex workers", above at note 14 at 206 
assistance in the debate. To date, there seems to be little movement in implementing the executive's seeming commitment to decriminalizing sex work.

\section{Moving forward}

The SALRC final report is a clear indication that many in South Africa (as elsewhere) are still being influenced by so-called "rescue politics" that insinuate that all sex workers should be saved and that salvation is necessary in order to protect "our daughters" from becoming possible trafficking victims. ${ }^{116}$ The report is disappointing as the South African government has shown clear commitment not only to decriminalization but also to the requirement to give heed to sex workers' constitutional rights.

The report indicates that developing policy responses to sex work remains complex. Freeman argues that adopting a sex work policy response would inevitably require support for either a liberal or a radical feminist argument, namely: resisting the commodification of women's sexuality, or supporting the right of women to do work that they say they want to do. ${ }^{117}$ Although Freeman is more sympathetic to the long-term views of radical feminists in eradicating all forms of sex work, she supports decriminalization as a shortterm measure, maintaining that current societal structures do not support its eradication. ${ }^{118}$ She contends that criminalization only complicates the lives of sex workers, and that the best short-term approach would be to remove sex work from the criminal realm in order to further gender equality, and with the long-term aim of destroying the conditions that drive male consumption. ${ }^{119}$

Bingham also supports decriminalization as a first step in helping sex workers to radically change their lives, irrespective of whether one supports either a liberal or a radical feminist theoretical approach to sex work. ${ }^{120}$ She maintains that decriminalization will assist in decreasing the stigma attached to sex work, which would, in the long run, benefit all sex workers.

Other scholars, such as Scoular and O'Neil, argue that responses to sex work should focus on a politics of inclusion that acknowledges the complexity of selling sex. ${ }^{121}$ This would require an understanding of the economic need, lack of viable options, poverty and conflict that create motivating agents for selling sex. ${ }^{122}$ Such a politics of inclusion would be grounded in recognizing

116 Mgbako “The mainstreaming of sex workers' rights as human rights", above at note 36 at 106.

117 Freeman "The feminist debate over prostitution reform", above at note 10 at 76.

118 Ibid.

119 Ibid.

120 Bingham "Nevada sex trade", above at note 60 at 98.

$121 \mathrm{~J}$ Scoular and M O'Neill "Legal incursions into supply/demand: Criminalising and responsibilising the buyers and sellers of sex in the UK" in VE Munro and M Della Giusta (eds) Demanding Sex: Critical Reflections on the Regulation of Prostitution (2008, Ashgate Publishing) 13.

122 Id at 25. 
multiple standpoints, experiences and realities of everyone (women, men and young people) involved in selling sex, locating these experiences within a framework of rights' recognition, respect and redistribution. ${ }^{123}$

African feminism(s), as opposed to traditional feminist standpoints, use an intersectional lens through which to view the realities of sex work and to focus on multiple oppressions, including gender, race and poverty. ${ }^{124}$ Kruger has highlighted the importance of an African feminist approach(es) to sex work that acknowledges multiple forms of oppression and views women first as human, rather than as sexual, beings. ${ }^{125}$ What has become evident from the African experience is the focus on a rights-based approach to sex work, and that rights, not criminalization, will best protect sex workers. With sex work decriminalized, sex workers would be legally recognized as workers and would have the same rights and recourse to services as other workers, allowing them to access the criminal justice system for actual protection against violence, and including better access to health care services. ${ }^{126}$

The recognition of sex work as work might imply that one is simply endorsing liberal feminist arguments insinuating that the development of sex work policy is merely a choice between traditional feminist theories. However, the influence of African feminism(s) and the focus on sex workers as the best representatives of the complexities of their own lives indicate how the evolution of traditional feminist theory has focused on the intricacies of women's actual needs within the context in which they live. Rights are the best way to ensure real palpable change for the women (and all individuals) involved in sex work.

Smith and Mac poignantly state that just because a job is bad, it does not mean it is not a real job. ${ }^{127}$ They assert that when sex workers claim that sex work is work, they are highlighting the need for rights; they are not saying that work is "good or fun, or even harmless, nor that it's a fundamental value", but that sex workers should not have to defend the sex industry in order to argue that they deserve the ability to earn a living without having to be punished. ${ }^{128}$

But the pull and influence of carceral feminism, combined with that of vocal anti-trafficking groups, remain considerable as their respective agendas are increasingly seen as the new pre-eminent vehicle for social justice. ${ }^{129}$ However, Mgbako, supporting decriminalization, argues that, by removing the fear of arrest for sex workers, those workers could be in a position to help identify situations of abuse and suspicion of actual trafficking. ${ }^{130}$

123 Id at 23.

124 Kruger "Sex work from a feminist perspective", above at note 9 at 143 .

125 Ibid.

126 Mgbako "The mainstreaming of sex workers' rights as human rights", above at note 36 at 106.

127 Smith and Mac "Revolting prostitutes", above at note 29 at 55.

128 Ibid.

129 Bernstein "Militarised humanitarianism", above at note 28 at 65.

130 Mgbako "The case for decriminalisation of sex work in South Africa", above at note 41 at 1442. 
Smith and Mac point to the fact that, for carceral feminists, the problem is commercial sex that leads to trafficking, and with criminal law and the police as the answer, whereas the real problem is migration and borders, with greater rights needed to protect migrants. ${ }^{131}$ The importance of decriminalization lies in removing power from the police and criminal justice system, which is a great source of sex worker exploitation, abuse and degradation. ${ }^{132}$

Understanding and adopting a rights-based framework in decriminalizing sex work would give effect to several South African constitutional rights, including rights to free choice of work, access to health care, security of the person and human dignity. ${ }^{133}$ But there needs to be a recognition and understanding that developing sex work policy does not have to be a choice over which specific feminist standpoint to adopt, but instead requires an evolving recognition of rights as a vehicle that could drive change. The South African government should guard against supporting traditional feminist discourses in developing a policy response. The SALRC final report, and with its unsubstantiated support for radical feminist ideology, is illustrative of the need to strengthen support for African feminist discourse, which would thus enable government to take greater cognizance of the lived realities of sex workers. ${ }^{134}$

\section{CONCLUDING REMARKS}

Since the initialization of the SALRC project over eighteen years ago, South Africa has made little headway in furthering and protecting the constitutional rights of sex workers. The final report has created confusion and has backtracked on developing a new policy response, leading to great uncertainty as to what parliament's response would be. With the SALRC final report seemingly contradicting the government's support for decriminalization, development of a new policy response to sex work in South Africa is not going to be an easy task, and a pertinent question remains as to whether expanding support for a rights-based framework would provide a clearer path in structuring policy reform.

The SALRC final report is devoid of any specific rights' analysis, and clearly supports a radical feminist approach to sex work without providing any theoretical justification. To some extent, the SALRC's final report is understandable in light of the Constitutional Court decision in $S v$ Jordan that dealt a blow to a rights-based approach in furthering sex work reform. There are also general criticisms in supporting a rights-based framework in furthering equality aims, as it potentially "constructs universal subjects that are devoid of

131 Smith and Mac "Revolting prostitutes", above at note 29 at 84.

132 Ibid.

133 Mgbako "The case for decriminalisation of sex work in South Africa", above at note 41 at 1446.

134 NI Aniekwu "Converging constructions: A historical perspective on sexuality and feminism in post-colonial Africa” (2006) 10 African Sociological Review 143 at 151. 
difference". ${ }^{135}$ To this end, Gouws highlights the fact that adopting a rights-based discourse can obscure conditions of inequality as they are linked to possessive individualism, disconnecting rights from the community and a reliance on others. ${ }^{136}$ Such a framework could also result in an overreliance on the state to give effect to rights, which could weaken the power of popular movements by allowing the state to define their goals. ${ }^{137}$ Despite criticism, scholars such as Schneider argue that rights can provide an important sense of collective identity, and when coupled with strong activism (such as with the active mobilization of SWEAT) provide a platform for promoting and effecting lasting change. ${ }^{138}$

Despite the restrictive finding in $S v$ Jordan, a focus on sex workers' constitutional rights has, for example, furthered their access to health care services. The South African National Sex Worker HIV Plan recognizes the need for a rights-based approach to sex work that prioritizes gender equality and gender rights. ${ }^{139}$ The plan specifically states that the criminalization of sex work has negatively impacted HIV prevention programmes and driven sex work underground. ${ }^{140}$ Decriminalizing sex work could be the first step in providing sex workers with greater rights' protection, but this would have to be followed up with clear policy directives. ${ }^{141}$

Sex worker rights activists have noted that the task of creating awareness of decriminalization and sex workers' rights is cumbersome, taking into consideration the dominant discourse of perceiving all sex workers as victims. ${ }^{142}$ As a result, most of their time is dedicated to sharing basic knowledge on sex work, with little time to consider complex ideas about intersections of sexism, racism and poverty in sex work. ${ }^{143}$ The decriminalization of sex work could assist in challenging the assumption that all sex workers are victims (and

135 A Gouws "Citizenship, gender equality and the limits of law reform in South Africa" in M Abraham et al (eds) Contours of Citizenship: Women, Diversity and Practices of Citizenship (2010, Ashgate Publishing) 147 at 148.

136 Ibid; also see D Lewis "Discursive challenges for African feminisms" (2006) 20 Quest: An African Journal of Philosophy 77 at 85.

137 A Gouws "Shaping women's citizenship: Contesting boundaries of state and discourse" in A Gouws (ed) (Un)thinking Citizenship: Feminist Debates in Contemporary South Africa (2005, Ashgate Publishing) 70 at 80.

138 Schneider "The dialectic of rights and politics", above at note 15 at 625.

139 South African National Sex Worker HIV Plan 2016-2019 (2016) at 15 and 33 available at: <https://southafrica.unfpa.org/sites/default/files/pub-pdf/South\%20African\%20Natio nal\%20Sex\%20Worker\%20HIV\%20Plan\%202016\%20-\%202019\%20FINAL\%20Launch\% 20Copy...\%20\%282\%29\%20\%281\%29.pdf> (last accessed 18 August 2020).

140 Ibid; also see A Scheibe, M Richter and J Vearey "Sex work and South Africa's health system: Addressing the needs of the undeserved" (2016) 19 South African Health Review 165 at 169.

141 C Overs and K Hawkins "Can rights stop the wrongs? Exploring the connections between framings of sex workers' rights and sexual and reproductive health” (2011) 11 BMC International Health and Human Rights 1 at 8.

142 Jackson "Framing sex worker rights", above at note 27 at 39.

143 Ibid. 
possible victims of trafficking) with the acknowledgment that sex workers are individuals who are able to express their own needs and wants. ${ }^{144}$

What is clear is that a new policy framework should recognize the realities of sex work, irrespective of support for a specific feminist theoretical approach. In considering its response to the SALRC's final report, the South African government should focus on sex workers' voices in furthering their constitutional rights. ${ }^{145}$ Realizing government's commitment to decriminalization would contribute to removing the stigma associated with sex work and enable further discussion in relation to women's vulnerability and the continued subjugation of their sexuality. Ultimately all sex workers deserve better clarity of their rights and protection than is the case under the current system of full criminalization, as well as the realization that in developing a policy response there is a definite need for a "politics of inclusion".

\section{Conflicts of interest}

None

145 Abel "A decade of decriminalisation", above at note 54 at 581. 